\title{
Personality Traits and Foreign Language Proficiency in Russian Linguistics and Non-Linguistics Students
}

\author{
Irina A. Novikova ${ }^{1}$, Nadezhda S. Berisha ${ }^{1,2}$, \\ Alexey L. Novikov ${ }^{1}$, Dmitriy A. Shlyakhta ${ }^{1}$
}

\author{
${ }^{1}$ Peoples' Friendship University of Russia (RUDN University) \\ 6 Miklukho-Maklaya St, Moscow, 117198, Russian Federation \\ ${ }^{2}$ The Russian Presidential Academy of National Economy and Public Administration \\ 82 Vernadskogo Ave, bldg 1, Moscow, 119571, Russian Federation
}

\begin{abstract}
The search for factors and determinants of effective foreign (second) language acquisition (FLA/SLA) is an interdisciplinary problem that is becoming more and more practically important in the modern globalising world. The purpose of this study is to examine and compare the correlation between personality traits and the foreign language proficiency (FLP) level among students of various university specialties. The total sample includes 241 first- and second-year undergraduate students (74\% females), of which 128 students $(82.5 \%$ females) study at the Linguistics Department and 113 students (64\% females) belong to other departments. All the students learn English as a primary foreign language (FL). The Five-Factor Model (FFM) of personality traits (Neuroticism, Extraversion, Openness, Conscientiousness, and Agreeableness) were measured by the NEO Five-Factor Inventory (Russian adaptation by S. Biryukov and M. Bodunov). In testing the foreign language proficiency levels, we used the traditional Academic Performance Index (semester Final Grades in English) and assessments of the foreign language proficiency levels made by English teachers in relation to their students according to the Foreign Language Proficiency Scale (10 indices and the total score) developed by the authors. To process the data in the R software environment, version 3.5.2, the methods of descriptive statistics, Cronbach's alpha and Macdonald's omega coefficients, Spearman's rank correlation analysis and Wilcoxon's $T$-test were used. The findings of our research showed that FLP is most closely related to Openness in linguistics students and to Conscientiousness in non-linguistics students. These facts should be taken into account by the developers of programmes for psychological and pedagogical support of the FL learning process in Russian universities.
\end{abstract}

Key words: foreign language, second language, foreign language acquisition, foreign language proficiency, Five-Factor Model, personality traits, English as a foreign language, linguistics and non-linguistics students

\section{Introduction}

Foreign language proficiency (FLP) is one of the most important competences of a modern person in the contemporary globalising world. Recently, the European Union adopted the concept of multilingualism that implies that every citizen should 
be fluent in at least three languages - native and two foreign (Korotova, Polyakov, 2015). At the same time, teachers, psychologists, linguists and representatives of related sciences continue to search for conditions and determinants that contribute to more effective foreign (second) language acquisition (FLA/SLA). Accordingly, researchers identified and studied numerous factors of FLA (Chebotareva, 2013; Gardner, 2008; Loewen, Sato, 2017; Malovrh, Benati, 2018; VanPatten, Benati, 2010 ; etc.) that can be put into several major groups:

1) social and socio-cultural factors (popularity and relevance of the target language; relationships between the native country and the target-language country; political situation in the world, etc.);

2) educational and pedagogical factors (features of the system, forms and methods for teaching a foreign language (FL);

3) linguistic factors (target language features and the degree of its similarity with the native one);

4) psychological and social psychological factors (numerous psychological qualities of students and teachers as well as features of interpersonal relationships between them); and

5) demographic and psycho-physiological factors (age, gender, nervous system peculiarities, etc.).

It should be noted that these factors are interrelated and can mediate each other, which shows the complexity of FLA problem studying. For example, The good language learner (GLL) studies (Griffiths, 2008; Johnson, 1999; etc.) revealed that "the notion of good language learner is a highly complex, including many different variables, such as socio-demographic characteristics, personality, motivation, style, beliefs, culture and aptitude, as well as some situational factors, which learners must recognise and flexibly adapt to" (Chebotareva, 2013. P. 562).

In this article, we will pay attention to psychological and especially personality factors, which we consider as belonging to the key factors in the complex FLA system.

FLA psychological factors. Among all FLA psychological factors, motivation is one of the most studied, which encourages and supports the entire FL studying process. Researchers investigate both the direct motivation to learn a foreign language, which may be associated with the desire for intercultural communication, studying or working abroad, etc., and the educational motivation in relation to a foreign language as academic subject (Chebotareva, 2013; Gardner, 2001; Zhang et al., 2020; etc.).

Much attention is paid to the study of language learning aptitudes, among which, first of all, the features of cognitive processes (sensory processes, perception, attention, creativity, different types of intelligence) are considered. For example, since the late 1950s, the Modern Language Aptitude Test (MLAT) has been widely used in the United States for the purposes of professional selection and determination of language aptitudes. This test includes five aspects: (1) number learning; (2) phonetic script; (3) spelling clues; (4) words in sentences; and (5) paired associates (Carroll, Sapon, 2002).

Many researchers note that the FLA features may be related not only to particular abilities, aptitudes or traits, but to certain communication strategies or styles 
of foreign language learning (Kasper, Kellerman, 1998). Thus, the Russian psychologist M.K. Kabardov and his colleagues (Kabardov, 2013; Kabardov, Artsishevskaya, 1996) identified three styles (types) of language learning: (1) communicative-speech; (2) cognitive-linguistic; and (3) mixed. The communicative-speech style is more focused on the study of foreign speech as a process of communication. Representatives of this type are distinguished by good auditory memory, predominance of involuntary attention and memory, impulsiveness, emotionality. Students of this type better learn a foreign language through practical tasks, acting out the situations, dialogues, etc.; therefore, communicative, 'intensive' FL teaching methods are best suited to them, during which they are 'immersed' in the language environment. The cognitive-linguistic style, on the contrary, is focused on studying a foreign language as a linguistic system. Representatives of this type have better developed visual memory, with dominating arbitrary attention and memory; they are not characterised by bright emotionality and expressiveness in communication, and they may experience fear of public speaking. Students of this type prefer 'traditional' FL teaching methods. Representatives of the mixed style combine certain characteristics of the communicative-speech and cognitive-linguistic styles; therefore, both traditional and intensive FL teaching methods are suitable for them.

Among the psychological factors that complicate FL learning, foreign language anxiety (i.e. experiencing tension, worry, anxiety while learning or using FL) is often mentioned, which blocks the spontaneous use of a FL in communication (Chebotareva, 2013; Gregersen, 2003; etc.). This type of anxiety is situational, i.e. people experience it in some situations and do not feel it in others. At the same time, it is obvious that anxiety as a personality trait can also affect the process and result of FLA. In our opinion, it is personality traits that can be a mediating link between the 'situational' and 'internal' factors of FLA; therefore, we shall consider them in more detail.

Personality traits as FLA factors. Different groups of personality traits are considered as the most important factors of success in studying a FL:

- volitional traits (persistence, initiative, conscientiousness, etc.), which help to overcome difficulties in studying a FL and achieve goals (Chebotareva, 2013; Krupnov et al., 2016; Novikova, Vorobyeva, 2017);

- cognitive traits (curiosity, creativity, openness to experience, etc.), which encourage interest and activity in learning (Krupnov et al., 2016); and

- communicative traits (sociability, communicativeness, agreeableness, etc.), which facilitate communication with other people, in particular, using a FL (Gardner, 2008).

Recently, a large number of studies of personality traits as FLA factors have been carried out in Russian psychology on the basis of the System-Functional Model by A.I. Krupnov (Krupnov et al., 2013; Krupnov et al., 2016; etc.). According to this model, personality traits are considered as a set of components and variables included into two subsystems: motivational-meaningful (attitudinal-target, motivational, cognitive and productive components) and regulatory-dynamic (dynamic, emotional, regulatory and reflexive-evaluative components) (Krupnov et al., 2013). Based on this model, the correlations of such traits as sociability, persistence, curiosity, initiative, and responsibility with FLA features were studied (Berisha et al., 
2018; Krupnov et al., 2017). In particular, it was shown that persistence as a volitional personality trait is more closely related to academic success in learning a FL than curiosity or initiative (Krupnov et al., 2016; Novikova, Vorobyeva, 2017; Vorobyeva, 2015). Krupnov, Kozhukhova and Vorobyova (2017) found out that persistence variables play an important role in the development of the FL phonetics. At the same time, it was found that the initiative, which as well as persistence refers to the volitional personality traits, had ambiguous relationship with FLA indicators. This contradiction can be explained by the fact that the students' desire to be more initiative during the FL classes is not always encouraged by FL teachers (Berisha et al., 2018; Krupnov et al., 2019).

In Western psychology a number of studies on personality traits as factors of educational achievements in general and in the FL/SL in particular were carried out on the basis of the Five Factor Model (FFM) by Robert R. McCrae and Paul T. Costa (McCrae, Costa, 2004; McCrae, John, 1992; etc.). The results of these studies show that among the five factors considered in the model (Neuroticism, Extraversion, Openness, Agreeableness, and Conscientiousness), it is the Conscientiousness (a volitional personality trait) that is the most universal predictor of educational achievements among people of different ages and educational levels and for most of the disciplines studied, including a FL (Ackerman et al., 2011; Hergüner, Mirici, 2016; Novikova, Vorobyova, 2017; Norfazlika et al., 2016; Poropat, 2009; Vedel, 2016; etc.).

Currently, the FFM is widely used in psychological research worldwide, including Russia. As suggested by A. Furnham and P. Heaven (1999), due to the fact that there are some cross-cultural variations in the description of the five personality factors, some differences have been established in the associations of the FFM traits with educational achievement in different cultures. For example, in some studies on Russian samples, there were no significant correlations found between the FFM traits and academic achievements in different disciplines; the authors explained this fact by the difference in the educational systems (Kochergina et al., 2013). Later, on different Russian samples, ambiguous and often contradictory results were revealed, which, on the whole, indicate less close connections between the personality traits and academic achievements than similar connections in international studies (Gavrilova, 2013; etc.). Of great interest to us are the results of the research on academic achievements among Russian linguistics students conducted by I. Novikova and A. Vorobyeva (Novikova, Vorobyeva, 2017; Vorobyeva, 2015). This research has shown that academic achievements of linguistics students in different groups of disciplines (the English Language, the Second FL, Special Linguistics Disciplines, General Education Disciplines, and Psychology \& Pedagogics) are closely related to Conscientiousness. At the same time, none of the FFM traits is associated with academic achievements in English, but three of them are associated with the second FL academic achievement: Conscientiousness and Extraversion have positive associations, Neuroticism has negative associations. The authors explain this by the fact that English is a compulsory subject and the majority of linguistics students have been studying it for a long time, and the second FL is chosen by the students, which is largely due to their individual psychological characteristics (Novikova, Vorobyeva, 2017). 
In our previous studies, we found only a few correlations between Openness and the FLP indices in linguistics students and, contrary to assumptions, there were no significant correlations between the FLA indices and Conscientiousness (Berisha et al., 2018). Moreover, the findings of further research showed that creativity have a stronger impact on the FLP level compared to personality traits (Novikova et al., 2020).

In our opinion, certain contradictions between the results of Russian and international studies on the associations between the FFM traits and FLA may be connected with the use of different criteria for FLP assessments (Rasskazova et al., 2017; Solnyshkina et al., 2016), which necessitates using additional FLA indices apart from academic achievements.

Based on the reviewed literature, we suggest that there are specific correlations between the FFM personality traits and EFL (English as a foreign language) proficiency indices among students of different specialisations, in particular, among linguistics students (EFL is the major subject) and non-linguistics students (EFL is one of the minor subjects). We assume that the success of studying EFL among non-linguistic students will be connected, first of all, with Conscientiousness but, as for linguistics students, it will be associated with Openness. The purpose of the empirical research presented in this article is to verify this hypothesis.

\section{Methods}

Participants. A total of 241 respondents took part in the research. All the respondents were first- and second-year undergraduate students aged from 18 to 23 years $(\mathrm{M}=18.59$, SD $=1.09)$, of which 128 students (22 males and 106 females) were studying at the Linguistics Department and 113 students (41 males and 72 females) belonged to non-linguistic departments (National Economy, World Economy and Psychological and Pedagogical Education). All the students learned English as their main FL.

All the participants were engaged in psychodiagnostic tests in accordance with the instructions in the presence of the experimenter after English classes. They were informed that participation would be free and voluntary.

In addition, 24 English teachers (100\% females) with EFL teaching experience from 1 year to 40 years participated in the study as experts. Each teacher assessed ten FL proficiency aspects among their students using the proposed scale (see below).

Statistical methods. The descriptive statistics methods, Cronbach' $\alpha$ and McDonald's $\omega$ coefficients, Spearman rank correlation analysis, and Wilcoxon' $T$-test were used for processing the data. Statistical processing was carried out in the R software environment for statistical computing and graphics, version 3.5.2 (R Core Team, 2018).

Techniques. To measure the FFM personality traits, we used the Five-Factor Inventory (FFI), which is the Russian version of the NEO Five Factors Inventory adapted by S. Biryukov and M. Bodunov (Bodunov, Biryukov, 1989). The FFI consists of 60 direct and inverted items, to which the subjects expressed their degree of consent using a 5-point Likert scale (from "strongly disagree" to "strongly agree"). The resulting values for each of the five personality factors (Neuroticism, 
Extraversion, Openness, Conscientiousness, and Agreeableness) range from 12 to 60 points. This short version of the questionnaire had been properly tested on different Russian samples (Gridunova et al., 2017; Novikova, Vorobyeva, 2017; Berisha et al., 2018).

To assess the level of FLP, we used the following two procedures.

1. The traditional Academic Performance Index (the semester grades in English, in the range from 0 to 100): for the linguistics students, it was the exam score in the EFL practical course; for the non-linguistics students, it was the exam score in English.

2. Assessments of the foreign language proficiency levels made by the English teachers in relation to their students, according to the Foreign Language Proficiency Scale (FLPS) developed by us. The English teachers acting as experts assessed their students using a quantitative 5-point scale (from 1 to 5) for each of the 10 following indices (abbreviations in brackets, which are further used in tables and in the figure):

1) speed and accuracy of perception foreign speech by ear (audition);

2) fluency of reading in a foreign language (reading);

3) lexical and grammatical correctness of writing (writing);

4) vocabulary (vocabulary);

5) lexical and grammatical correctness of oral speech (speaking);

6) level communication skills in a foreign language (communication);

7) pronunciation (phonetics);

8) initiative and activity in the classroom (initiative);

9) diligence and care in preparing homework (diligence);

10) creativity while studying a foreign language (creativity).

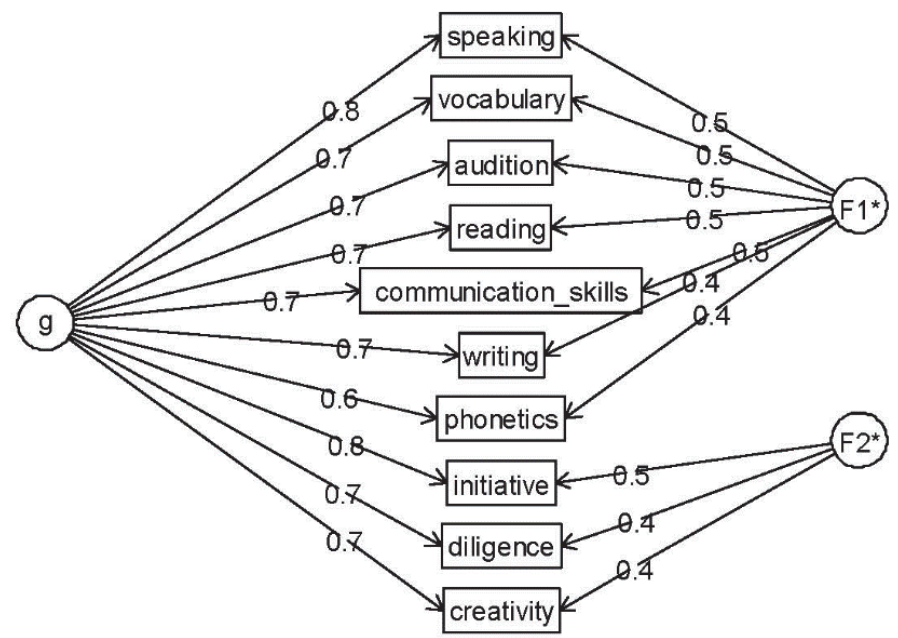

Figure. Internal consistency verification of the FLPS results $(\alpha=0.95, \omega=0.78)$

Note: $g$ - common factor; F1, F2 - specific factors.

The FLPS includes not only the 'traditional' FLA indices (listening, reading, writing, speaking, etc. - indices 1-7) but also, in accordance with the purpose of the present study, the assessment of personality characteristics that are important in the process of learning a FL (indices 8-10). 
Figure shows the results of the FLPS psychometric testing using McDonald's $\omega$ and Cronbach's $\alpha$ coefficients. The verification data indicate that the FLPS has a very high degree of internal consistency of all items $(\omega=0.78, \alpha=0.95)$ and therefore of its internal validity. At the same time, all the FLPS indices have significant positive correlations with the Final Grades $\left(r_{s}=0.40-0.73, p \leq 0.001\right)$, which confirms the external validity of the proposed scale, as the semester exam is assessed by another teacher.

Figure also shows that, as it was expected, the FLPS points are combined into two factors (subscales): the first factor (F1) includes the assessment of 'traditional' FLP, and the second factor (F2) includes the assessment of students' personality traits that can contribute to FLA. For further calculations, we used all the 10 indices of the FLPS separately (in the range from 1 to 5 points), the sum on the subscale $F 1$ (in the range from 7 to 35 points), the sum on the subscale $F 2$ (in the range from 3 to 15 points), and the Total Scores on the FLPS (in the range from 10 to 50 points).

\section{Results and discussion}

Table 1 presents the results of descriptive statistics of all the studied variables (FFM traits and FLP assessment indices) for the total sample and for the subsamples of the linguistics and non-linguistics students as well as Wilcoxon' $T$-test results between these subsamples.

The first part of the Table 1 shows that there are no significant differences between most FLP assessments in the linguistics and non-linguistics students (excluding Final Grades). It is explained by the fact that the experts assessed the students based on the requirements of the relevant discipline (linguistic or non-linguistic), they did not need to assess the absolute level of FLP. Moreover, there are no generally accepted criteria for assessing this level in the Russian university system (Rasskazova et al., 2017; Solnyshkina et al., 2016). We should note that all the students received relatively higher average grades in reading and relatively lower average grades in such FL aspects as speaking, writing, and phonetics, which corresponds to the hierarchy of difficulties faced by Russian FL learners (Soselia, Chebotareva, 2007).

Most of the tested students were rated as 'Good' and 'Excellent' ( $\mathrm{C}$ and $\mathrm{B}$ on the ECTS scale) in the semester exam, but the average Final Grades of the linguistics students are slightly lower than those of the non-linguistics students (84.13 and 85.66 respectively, $p=0.003$ ). Most likely, this difference is explained by the higher requirements applied to the linguistic students, for whom English is one of the majors.

It is interesting that, despite the minimal differences in the FLP assessment between the linguistics and non-linguistics students, some differences in the FFM personality traits were revealed between them. The second part of the Table 1 shows that the linguistics students have higher Neuroticism but lower Extraversion, Conscientiousness, and Agreeableness than the non-linguistics students (no significant differences were found in Openness). A. Furnham and P. Heaven (1999), based on the meta-analysis of numerous studies, also showed the differences in the personality traits between students of different fields of study, which are most pronounced in Conscientiousness, as is the case in our study. 
Means (M), standard deviations (SD) and Wilcoxon' $T$-test between the studied variables in the linguistics and non-linguistics students

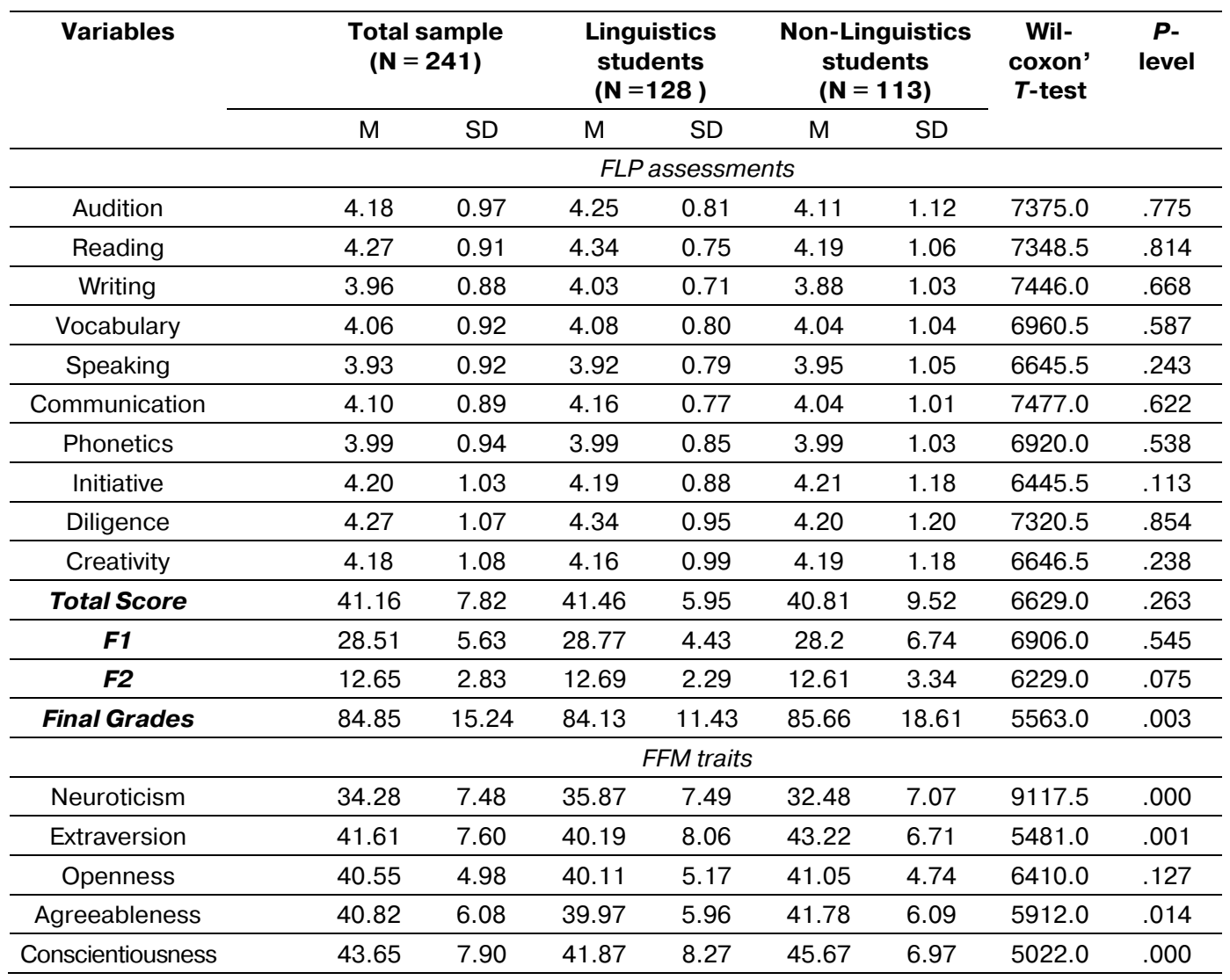

According to the research hypothesis, the most important data are the correlations between the FFM personality traits and FLP assessment indices (Table 2).

Table 2 shows that Conscientiousness is most closely related to most of the FLP assessments (except audition, vocabulary, and phonetics) in the total sample of the students studying EFL. This fact filly corresponds to the data of numerous studies on the correlations between the FFM personality traits and academic achievements in various national samples and in different fields of study (Ackerman et al., 2011; Hergüner, Mirici, 2016; Poropat, 2009; Vedel, 2016; etc.). However, if we consider the correlation between the studied variables separately among the linguistics and non-linguistics students, the differences between these groups are clearly seen.

As in the total sample, in the non-linguistics students' subsample, Conscientiousness has positive correlations with almost all the FLP assessments (except phonetics), which confirms the importance of volitional traits for success in learning a FL as a non-profiled subject (Chebotareva, 2013; Krupnov at al., 2017). It is logical that the closest correlations were revealed between Conscientiousness and the FLP assessment indices, which characterise the students' personality traits and their attitude to learning EFL (initiative, diligence, creativity, as well as the F2 subscale, which includes these indices). Also, Agreeableness has positive correlations with initiative, diligence, and F2 subscale in the non-linguistics students; therefore, friendly, altruistic, open-minded students are considered by the teachers as 
being more initiative, active, careful and diligent in learning English. Finally, there is another significant but negative correlation between Neuroticism and audition (listening) in this subsample (this fact shows that more emotionally unstable students perceive foreign speech worse by ear, which can be caused by excessive anxiety).

Table 2

Spearman rank correlations between the FFM personality traits and the FLP assessments

\begin{tabular}{|c|c|c|c|c|c|c|c|c|c|c|c|c|c|c|c|}
\hline \multirow{2}{*}{$\begin{array}{c}\text { FLA } \\
\text { assess- } \\
\text { ments }\end{array}$} & \multicolumn{3}{|c|}{ Neuroticism } & \multicolumn{3}{|c|}{ Extraversion } & \multicolumn{3}{|c|}{ Openness } & \multicolumn{3}{|c|}{ Agreeableness } & \multicolumn{3}{|c|}{ Conscientiousness } \\
\hline & TS & LS & NLS & TS & LS & NLS & TS & LS & NLS & TS & LS & NLS & TS & LS & NLS \\
\hline Audition & -.04 & .09 & $-.20^{*}$ & .00 & -.06 & .04 & .05 & $.17^{*}$ & -.09 & -.01 & .09 & .07 & .11 & -.15 & $.37^{*}$ \\
\hline Reading & -.05 & -.04 & -.09 & .01 & -.03 & .05 & .07 & .14 & -.02 & .04 & .04 & .14 & $.16^{* *}$ & .04 & $.30^{* *}$ \\
\hline Writing & -.05 & -.05 & -.08 & -.06 & -.09 & -.04 & .09 & $.17^{*}$ & .00 & .03 & .01 & .07 & $.17^{* *}$ & .09 & $.27^{*+1}$ \\
\hline Vocabulary & -.04 & -.06 & -.02 & -.05 & -.08 & -.05 & .06 & .12 & -.03 & .00 & .08 & .08 & .09 & -.09 & $.26^{* *}$ \\
\hline Speaking & -.13 & -.12 & -.13 & -.02 & -.05 & -.06 & .08 & .15 & -.04 & -.02 & .10 & .01 & $.21^{* * *}$ & .08 & $.32^{* * *}$ \\
\hline $\begin{array}{l}\text { Commu- } \\
\text { nication }\end{array}$ & -.09 & -.10 & -.12 & -.04 & -.06 & -.03 & -.01 & .05 & -.07 & -.07 & .15 & .02 & $.16^{* *}$ & .03 & $.30 *$ \\
\hline Phonetics & .05 & -.01 & .11 & -.01 & .05 & -.10 & -.01 & .07 & -.12 & .01 & .02 & .00 & .08 & .01 & .14 \\
\hline Initiative & -.11 & -.03 & -.15 & .09 & .08 & .03 & .01 & -.01 & .01 & .08 & .09 & $.22^{*}$ & $.30^{* * *}$ & .10 & $.49^{* * * *}$ \\
\hline Diligence & -.04 & -.01 & -.10 & .02 & -.03 & .06 & .09 & $.19^{*}$ & -.01 & $.20^{* * *}$ & .14 & $.27^{\ldots *}$ & $.28^{* * *}$ & .11 & $.48^{* * * *}$ \\
\hline Creativity & -.03 & .08 & -.11 & .12 & .12 & .06 & $.19^{* * *}$ & $.23^{* *}$ & .12 & .07 & .04 & .15 & $.24^{* * *}$ & .03 & $.44^{* * *}$ \\
\hline $\begin{array}{l}\text { Total } \\
\text { Score }\end{array}$ & -.07 & -.02 & -.10 & .00 & -.03 & -.04 & .09 & $.19^{*}$ & -.06 & .05 & .07 & .12 & $.25^{* * *}$ & .05 & $.42^{* * * *}$ \\
\hline$F 1$ & -.07 & -.05 & -.07 & -.03 & -.04 & -.06 & .07 & $.17^{*}$ & -.08 & -.01 & -.10 & .06 & $.18^{* * *}$ & .03 & $.31^{\star \star \star}$ \\
\hline$F 2$ & -.07 & .04 & -.13 & .10 & .07 & .05 & .10 & .16 & .02 & $.14^{*}$ & -.01 & $.22^{*}$ & $.34^{* * *}$ & .11 & $.52^{* \star \star \star}$ \\
\hline $\begin{array}{l}\text { Final } \\
\text { Grades }\end{array}$ & -.10 & .04 & -.15 & .04 & .01 & -.03 & .11 & $.26 *$ & -.01 & .05 & .03 & .02 & $.27^{* * *}$ & .08 & $.37^{* * *}$ \\
\hline
\end{tabular}

Note: ${ }^{*}-p \leq 0.05 ;{ }^{* *}-p \leq 0.01 ;{ }^{* *}-p \leq 0.001$; TS - total sample ( $\left.\mathrm{N}=241\right)$; LS - linguistics students $(\mathrm{N}=128)$; NLS - non-linguistics students $(\mathrm{N}=113)$.

In the linguistics students' subsample, only Openness has positive correlations with several FLP assessments made by the experts (audition, writing, diligence, creativity, F1 subscale, and Total Score) and with the Final Grades. It should be emphasised that there was no significant correlation between the FLP assessments used in our study and other FFM personality traits (including Conscientiousness) in this subsample. In general, these results are consistent with the findings of numerous international studies that Openness is one of the powerful predictors of academic achievements. However, the relationship between the FFM personality traits and academic achievements may depend on both the field of students' study and on cross-cultural differences (Furnham, Heaven, 1999). Our data best correspond to the results of the Russian linguistics students' study by A.A. Vorobyeva (2015), which also did not reveal any correlation between Conscientiousness and Final Grades in EFL. 


\section{Conclusion}

Thus, in modern conditions of increasing globalisation, information flows, and digital technologies, the problem of efficient FLA is becoming more and more relevant. Accordingly, the development of FL teaching methods continues, which will take into account the numerous factors that mediate the process and results of the FL learning. One of the areas of psychological research that is in demand in this regard is the search for FLA personality factors and predictors, which will allow an individual approach to be applied and, accordingly, make FL learning more successful.

A large number of relevant studies in different countries, including Russia, are based on the Five-Factor Model (Ackerman et al., 2011; Berisha et al., 2018; Hergüner, Mirici, 2016; Novikova, Vorobyova, 2017; Poropat, 2009; Vedel, 2016; etc.). In addition, in Russia, the System-Functional Model of personality traits is widely used in corresponding research (Krupnov et al., 2016; Krupnov et al., 2017; etc.). Recently, attempts have been made to combine the potential of these personality models (Berisha et al., 2018; Krupnov et al., 2016; Vorobyeva, 2015).

Summing up the results of the present study on the correlation between the FFM personality traits and FLP in the linguistics and non-linguistics students, we can conclude that:

1) the FFM personality traits are one of the important factors in choosing a FL as a subject of study as well as in being successful in FLA;

2) linguistics students differ from non-linguistics ones by higher Neuroticism, lower Extraversion, Conscientiousness, and Agreeableness;

3) for linguistics students, the most significant FFM trait for FLP is Openness;

4) for non-linguistics students, the most significant FFM trait for FLP is Conscientiousness, which corresponds to the results of numerous studies in different national samples, including Russia (however, there are contradictory results in several studies).

Thus, in general, our assumption was confirmed that the correlations between FFM personality traits and FLA indicators may vary depending on students' field of study and whether the FL is the major or minor academic discipline.

The main limitations of our research are related to the fact that, firstly, we used the FLP assessments largely based on teachers' opinions, which may be subjective; secondly, as for the non-linguistic students, we studied only students of the socio-economic and psychological-pedagogical fields of study (where female students predominate); and, thirdly, we considered only English as a target FL. The results of our research could also be influenced by the peculiarities of the Russian educational system and the features of FL teaching methods in Russia.

Summing up all the findings and limitations of our research, we have determined the following future prospects: (1) expansion of the sample via the inclusion of other fields of study students as well as balancing the female-to-male ratio; (2) additional use of more objective FLP assessment methods, such as TOEFL, MLAT, etc.; (3) consideration of other languages studied as second (or third) FL; (4) use of additional statistical processing methods, for example, dispersion and regression analysis; and (5) development and testing of the programmes for psychological and pedagogical support of the FL learning process in Russian universities, taking into account the research findings.

Acknowledgements and Funding. This publication was prepared as part of the Research Initiative Project No. 056112-0-000 at the Philological Faculty of RUDN University. 


\section{References}

Ackerman, P.L., Chamorro-Premuzic, T., \& Furnham, A. (2011). Trait complexes and academic achievement: Old and new ways of examining personality in educational contexts. British Journal of Educational Psychology, 81(1), 27-40. https://doi.org/10.1348/000709910x522564

Berisha, N.S., Novikov, A.L., Novikova, I.A., \& Shlyakhta, D.A. (2018). Individual and personal factors for successful learning of a foreign language by linguistics students. Izv. Saratov Univ. (N.S.). Ser. Educational Acmeology. Developmental Psychology, 7(1), 4-15. https://doi.org/10.18500/2304-9790-2018-7-1-4-15 (In Russ.)

Bodunov, M.V., \& Biryukov, S.D. (1989). Big 5: Five-Factor Inventory. Adapted and reproduced by special permission of the Publisher. Form S. Moscow: Institute of Psychology of RAS.

Carroll, J.B., \& Sapon, S. (2002). Modern Language Aptitude Test: Manual. Bethesda, MD: Second Language Testing, Inc.

Chebotareva, E.Ju. (2013). Foreign language acquisition. In K.D. Keith (Ed.), The Encyclopedia of Cross-Cultural Psychology (pp. 560-564). Hoboken, New Jersey: Wiley-Blackwell. https://doi.org/10.1002/9781118339893.wbeccp226

Furnham, A., \& Heaven, P. (1999). Personality and Social Behaviour. London: Arnold.

Gardner, R. (2008). Individual differences in second and foreign language learning. In N.H. Hornberger (Ed.), Encyclopedia of Language and Education (pp. 1135-1146). Boston, MA: Springer. https://doi.org/10.1007/978-0-387-30424-3_87

Gardner, R.C. (2001). Language Learning Motivation: the Student, the Teacher, and the Researcher. Texas Papers in Foreign Language Education, (6), 1-18.

Gavrilova, E.V. (2013). The Effect of the Educational environment on the formation of individual psychological characteristics and school motivation in high school students. Siberian Pedagogical Journal, (6), 256-259. (In Russ.)

Gregersen, T.S. (2003). To Err Is Human: A reminder to teachers of language-anxious students. Foreign Language Annals, 36(1), 25-32. https://doi.org/10.1111/j.1944-9720.2003.tb01929.x

Gridunova, M.V., Novikova, I.A., Radoev, M., \& Shlyakhta, D.A. (2017). The relation between intercultural competence, personality features and students' intellectual development). Zbornik Instituta za Pedagoška Istraživanja, 49(1), 77-78. https://doi.org/10.2298/ZIPI1701077G (In Serbian.)

Griffiths, C. (Ed.). (2008). Lessons from Good Language Learners. Cambridge: Cambridge University Press. https://doi.org/10.1017/cbo9780511497667

Hergüner, S., \& Mirici, İ.H. (2016). The relationship among trait emotional intelligence, big five personality traits and the academic success of EFL learners. International Journal of Language Academy, (4/3), 225-243. https://doi.org/10.18033/ijla.435

Johnson, K. (1999). Good language learner studies. In K. Johnson \& H. Johnson (Eds.), Encyclopedic Dictionary of Applied Linguistics (pp. 141-142). Cambridge: Blackwell Publishers.

Kabardov, M.K. (2013). Yazykovye Sposobnosti: Psikhologiya, Psikhofiziologiya, Pedagogika. Moscow: Smysl Publ. (In Russ.)

Kabardov, M.K., \& Artsishevskaya, E.V. (1996). Tipy yazykovykh i kommunikativnykh sposobnostey i kompetentsii. Voprosy Psikhologii, (1), 34-49. (In Russ.)

Kasper, G., \& Kellerman, E. (1998). Communication Strategies. London: Routledge. https://doi.org/10.4324/9781315844350

Kochergina, E.V., Nye, J., \& Orel, E.A. (2013). The Big Five traits as predictors of academic achievements in university students. Psychological Studies, (27), 4-10. (In Russ.)

Korotova, I.A., \& Polyakov, D.D. (2015). Concept of multilingualism as strategy of language policy and foreign-language education in Europe. RUDN Journal of Psychology and Pedagogics, (1), 54-60. (In Russ.)

Krupnov, A., Novikova, I., Berisha, N., \& Novikov, A. (2019). Initiative and second language acquisition in linguistics and non-linguistics students. EDULEARN19 Proceedings. $11^{\text {th }}$ International Conference on Education and New Learning Technologies (pp. 4635-4642). Palma: IATED. https://doi.org/10.21125/edulearn.2019.1153 
Krupnov, A.I., Kozhukhova, Y.V., \& Vorobyeva, A.A. (2017). Persistence and Academic Achievement in Foreign Language in Natural Sciences Students. RUDN Journal of Psychology and Pedagogics, 14(2), 143-154. https://doi.org/10.22363/2313-1683-2017-14-2-143-154

Krupnov, A.I., Novikova, I.A., \& Kozhukhova, Y.V. (2013). System-Functional Model of personality traits. Academic Journal of Interdisciplinary Studies, 2(9), 407-413. https://doi.org/10.5901/ajis.2013.v2n9p407

Krupnov, A.I., Novikova, I.A., \& Vorobyeva, A.A. (2016). On the problem of relation between the System-Functional and the Five-Factor Models of personality traits. RUDN Journal of Psychology and Pedagogics, (2), 45-56. (In Russ.)

Loewen, S., \& Sato, M. (Eds.). (2017). The Routledge Handbook of Instructed Second Language Acquisition. New York: Routledge. https://doi.org/10.4324/9781315676968

Malovrh, P.A., \& Benati, A.G. (Eds.). (2018). The Handbook of Advanced Proficiency in Second Language Acquisition. Hoboken: Willey Blackwell. https://doi.org/10.1002/9781119261650

McCrae, R.R., \& Costa, P.T. (2004). A contemplated revision of the NEO Five-Factor Inventory. Personality and Individual Differences, 36, 587-596. https://doi.org/10.1016/s01918869)03)00118-1

McCrae, R.R., \& John, O.P. (1992). An introduction to the Five-Factor Model and its applications. Journal of Personality, 60(2), 175-215. https://doi.org/10.1111/j.1467-6494.1992.tb00970.x443

Norfazlika, A.K., Dzeelfa, Z.A., \& Siti, A. (2016). Personality factors and second language acquisition: An Islamic viewpoint. International Journal of Business, Economics and Law, 11, 1-17.

Novikova, I.A., \& Vorobyeva, A.A. (2017). Big Five Factors and academic achievement in Russian students. Psychology in Russia: State of the Art, 10(4), 93-106. https://doi.org/10.11621/pir.2017.0409

Novikova, I.A., Berisha, N.S., Novikov, A.L., \& Shlyakhta, D.A. (2020). Creativity and personality traits as foreign language acquisition predictors in university linguistics students. Behavioural Sciences, 10(1), 35. https://doi.org/10.3390/bs10010035

Poropat, A.E. (2009). A meta-analysis of the Five-Factor model of personality and academic performance. Psychological Bulletin, 135, 322-338. https://doi.org/.1037/a0014996

R Core Team. (2018). R: A Language and Environment for Statistical Computing. Vienna: $\mathrm{R}$ Foundation for Statistical Computing.

Rasskazova, T., Muzafarova, A., Daminova, J., \& Okhotnikova, A. (2017). Assessing Russian university students' foreign language competence: Challenges and prospects. Proceedings of INTED2017 Conference (pp. 4610-4619). Valencia: IATED.

Solnyshkina, M.I., Harkova, E.V., \& Kiselnikov, A.S. (2016). Language assessment course: Structure, delivery and learning outcomes. International Journal of Environmental \& Science Education, 11(6), 1223-1229.

Soselia, I.L., \& Chebotareva, E.Ju. (2007). Motivational difficulties of mastering a foreign language. RUDN Journal of Psychology and Pedagogics, (3-4), 117-125.

VanPatten, B., \& Benati, A.G. (2010). Key Terms in Second Language Acquisition. London, New York: Continuum International Publishing Group. (Key Terms series).

Vedel, A. (2016). Big Five group differences between academic majors: a systematic review. Personality and Individual Differences, 101, 523. https://doi.org/10.1016/j.paid.2016.05.332

Vorobyeva, A.A. (2015). Volitional and Cognitive Personal Traits as Factors of Academic Achievement in the Students. Ph.D. in Psychology Thesis. Moscow: RUDN University. (In Russ.)

Zhang, H., Dai, Y., \& Wang, Y. (2020). Motivation and second foreign language proficiency: The mediating role of foreign language enjoyment. Sustainability, 12, 1302. https://doi.org/10.3390/su12041302

Article history:

Received: 14 June 2020

Revised: 5 August 2020

Accepted: 15 August 2020 


\title{
For citation:
}

Novikova, I.A., Berisha, N.S., Novikov, A.L., \& Shlyakhta, D.A. (2020). Personality Traits and Foreign Language Proficiency in Russian Linguistics and Non-Linguistics Students. RUDN Journal of Psychology and Pedagogics, 17(3), 426-439. http://dx.doi.org/10.22363/23131683-2020-17-3-426-439

\section{Bio notes:}

Irina A. Novikova, Ph.D. in Psychology, is Associate Professor, Associate Professor at Social and Differential Psychology Department, Peoples' Friendship University of Russia (RUDN University) (Moscow, Russia). ORCID iD: https://orcid.org/0000-0001-5831-1547, eLIBRARY SPIN-code: 7717-2834, Scopus ID: 35766733000, Researcher ID: Q-5276-2016. E-mail: novikova-ia@rudn.ru

Nadezhda S. Berisha, MA in Linguistics, is lecturer at Department of Political and Legal Disciplines and Social Communications, the Russian Presidential Academy of National Economy and Public Administration, and Ph.D. applicant at Social and Differential Psychology Department, Peoples' Friendship University of Russia (RUDN University) (Moscow, Russia). eLIBRARY SPIN-code: 4695-7330, Scopus ID: 57214097063. E-mail: terentyeva-ns@rudn.ru

Alexey L. Novikov, Ph.D. in Philology, Associate Professor, is Associate Professor at the General and Russian Linguistics Department, Peoples' Friendship University of Russia (RUDN University) (Moscow, Russia). ORCID iD: https://orcid.org/0000-0003-34825070, eLIBRARY SPIN-code: 3416-1350, Scopus ID: 56005222400, Researcher ID: Q5419-2016. E-mail: Novikov-al@rudn.ru

Dmitriy A. Shlyakhta, Ph.D. in Psychology, Associate Professor, is Associate Professor at Social and Differential Psychology Department, Peoples' Friendship University of Russia (RUDN University) (Moscow, Russia). eLIBRARY SPIN-code: 6172-5460, Scopus ID: 57191998066. E-mail: shlyakhta-da@rudn.ru

Исследовательская статья

\section{Личностные черты \\ и уровень владения иностранным языком у российских студентов-лингвистов и нелингвистов}

\author{
И.А. Новикова ${ }^{1}$, Н.С. Бериша ${ }^{1,2}$, А.Л. Новиков ${ }^{1}$, Д.А. Шляхта ${ }^{1}$ \\ ${ }^{1}$ Российский университет дружбы народов \\ Российская Федераиия, 117198, Москва, ул. Миклухо-Маклая, 6 \\ ${ }^{2}$ Российская академия народного хозяйства и государственной службы \\ при Президенте Российской Федерации \\ Российская Федераџия, 119571, Москва, пр. Вернадского, д. 82, стр. 1
}

\begin{abstract}
Аннотация. Поиск факторов и условий эффективного овладения иностранным (вторым) языком - междисциплинарная проблема, которая становится все более актуальной в современном глобализирующемся мире. Цель данного исследования - изучить и сравнить взаимосвязь между личностными чертами и уровнем владения иностранным языком у студентов различных направлений обучения. Выборка включает 241 студента первого и второго курсов (74 \% - девушки), из которых 128 студентов $(82,5 \%$ - девушки) учатся в бакалавриате по направлению «Лингвистика», а 113 студентов (64 \% - девушки) обу-
\end{abstract}


чаются по нелингвистическим направлениям. Все студенты изучают английский как основной иностранный язык. Для диагностики личностных черт (нейротизм, экстраверсия, открытость опыту, добросовестность и согласие) применялся пятифакторный опросник в русской адаптации С.Д. Бирюкова и М.В. Бодунова. Для определения уровня владения иностранным языком использовались как традиционный показатель академической успеваемости (итоговые семестровые оценки по английскому языку), так и процедура экспертной оценки. Преподаватели английского языка оценивали своих студентов с помощью авторской шкалы владения иностранным языком (10 показателей и общий балл). Для статистической обработки данных в программной среде R (версия 3.5.2) использовались методы описательной статистики, коэффициенты $\alpha$ Кронбаха и $\omega$ МакДональда, ранговый корреляционный анализ Спирмена и $T$-критерий Вилкоксона. Результаты исследования показали, что уровень владения иностранным языком наиболее тесно связан с открытостью опыту у студентов-лингвистов и добросовестностью у студентов-нелингвистов. Полученные данные могут быть использованы при разработке программ психолого-педагогического сопровождения процесса обучения иностранным языкам в российских вузах.

Ключевые слова: иностранный язык, освоение иностранного языка, уровень владения иностранным языком, пятифакторная модель личности, личностные черты, английский язык как иностранный, студенты-лингвисты, студенты-нелингвисты

Благодарности и финансирование. Статья подготовлена в рамках инициативной темы филологического факультета РУДН № 056112-0-000.

\section{История статьи:}

Поступила в редакцию: 14 июня 2020 г.

Принята к печати: 15 августа 2020 г.

\section{Для цитирования:}

Novikova I.A., Berisha N.S., Novikov A.L., Shlyakhta D.A. Personality traits and foreign language proficiency in Russian linguistics and non-linguistics students // Вестник Российского университета дружбы народов. Серия: Психология и педагогика. 2020. Т. 17. № 3. C. 426-439. http://dx.doi.org/10.22363/2313-1683-2020-17-3-426-439

\section{Сведения об авторах:}

Новикова Ирина Александровна, кандидат психологических наук, доцент, доцент кафедры социальной и дифференциальной психологии Российского университета дружбы народов (Москва, Россия). ORCID iD: https://orcid.org/0000-0001-5831-1547, eLIBRARY SPIN-код: 7717-2834, Scopus ID: 35766733000, ResearcherID: Q-5276-2016. E-mail: novikova-ia@rudn.ru

Бериша Надежда Сергеевна, магистр лингвистики, преподаватель кафедры политических и юридических дисциплин и социальной коммуникации Российской академии народного хозяйства и государственной службы при Президенте РФ, соискатель кафедры социальной и дифференциальной психологии Российского университета дружбы народов (Москва, Россия). eLIBRARY SPIN-код: 4695-7330, Scopus ID: 57214097063. E-mail: berisha-ns@ranepa.ru

Новиков Алексей Львович, кандидат филологических наук, доцент, доцент кафедры общего и русского языкознания Российского университета дружбы народов (Москва, Россия). ORCID iD: https://orcid.org/0000-0003-3482-5070, eLIBRARY SPIN-код: 3416-1350, Scopus ID: 56005222400, ResearcherID: Q-5419-2016. E-mail: novikov-al@rudn.ru

Шляхта Дмитрий Александрович, кандидат психологических наук, доцент, доцент кафедры социальной и дифференциальной психологии Российского университета дружбы народов (Москва, Россия). eLIBRARY SPIN-код: 6172-5460, Scopus ID: 57191998066. E-mail: shlyakhta-da@rudn.ru 